\title{
Evaluation of pancreatin stability through enzyme activity determination
}

\author{
GLEYSSON DE PAULA TERRA \\ MARCUS VINÍCIUS DE FARIAS RAMOS \\ MARCELLO GARCIA TREVISAN \\ JERUSA SIMONE GARCIA* \\ Federal University of Alfenas \\ - UNIFAL-MG, Institute of Chemistry \\ Laboratory of Analysis and \\ Characterization of Pharmaceuticals \\ Alfenas, Minas Gerais, Brazil
}

Accepted January 11, 2016

Published online May 31, 2016

\begin{abstract}
Pancreatin is a biotechnological product containing an enzyme complex, obtained from porcine pancreas, that is employed in treating pancreatic diseases. Experiments regarding the stability of the pharmaceutical formulation containing pancreatin were performed using standard binary mixtures with 6 excipients in a 1:1 ratio $(\mathrm{m} / \mathrm{m})$ and a commercial formulation. To accomplish these goals, samples were stored for 1,3 and 6 months at $40 \pm 1{ }^{\circ} \mathrm{C}$ and $75 \pm$ $5 \%$ relative humidity (RH) and $40 \pm 1{ }^{\circ} \mathrm{C}$ and $0 \% \mathrm{RH}$. Stress testing was also performed. All samples were analyzed to evaluate the $\alpha$-amylase, lipase and protease activities through UV/Vis spectrophotometry. The results revealed that the excipient proprieties and the storage conditions affected enzyme stability. Humidity was a strong influencing factor in the reduction of $\alpha$-amylase and protease activities. Stress testing indicated that $\mathrm{pH} 9.0$ and UV light did not induce substantial alterations in enzyme activity.
\end{abstract}

Keywords: $\alpha$-amylase, lipase, protease, stress testing, pancreatin stability, biopharmaceutical, UV/VIS spectrophotometry

Stability of pharmaceutical products depends on various factors, including environmental factors (e.g., temperature, humidity and light) and other factors related to the product itself, such as the physicochemical properties of active substances and pharmaceutical excipients, the shape and composition of the pharmaceutical, the fabrication process, and the type and properties of packaging materials (1).

For pharmaceutical products, the stability of biopharmaceuticals could require special attention because of their inherent physicochemical complexity. In this sense, stability tests are performed to determine the expiration date, the utilization period and the storage conditions. During the various fabrication stages of these biopharmaceuticals, aggregates and degradation products might form and compromise the stability, quality and security of the formulations (2).

Pancreatin is a biopharmaceutical obtained from swine pancreas, and according to the United State Pharmacopoeia, it is defined as a substance that contains enzymes, mainly

\footnotetext{
*Correspondence; e-mail: jerusa.garcia@unifal-mg.edu.br
} 
$\alpha$-amylase, lipase and protease that show pharmaceutical importance as therapeutic agents in acute and chronic pancreatitis (3).

There are few studies $(2,4)$ related to the enzyme activity of the pancreatin complex. Thus, the main objective of the present study was to evaluate the stability of formulations containing pancreatin. For this purposes, experiments using standard pancreatin and its binary mixtures with different excipients (ratio of $1: 1, \mathrm{~m} / \mathrm{m}$ ) were performed. In addition, the stability of the commercial formulation containing pancreatin was evaluated. Stress testing was also performed on pancreatin.

The activities of the three enzymes ( $\alpha$-amylase, lipase and protease) in all samples were analyzed through spectrophotometric tests, recommended by the ICH Q5C guidelines (5), which include elaborate guidelines concerning assays to determine the quality of biological and biotechnological products.

\section{EXPERIMENTAL}

Samples

The influence of excipients and storage conditions on enzyme stability was determined for samples of standard pancreatin (Sigma-Aldrich, USA), the commercial formulation and binary mixtures of standard pancreatin with each excipient (citric acid, magnesium stearate, mannitol, microcrystalline cellulose, sucrose and talc) at a 1:1 ratio $(\mathrm{m} / \mathrm{m})$. The excipients (99\% degree of purity) were provided by Aché Laboratórios Farmacêuticos S.A. Stress testing analysis was only performed for standard pancreatin.

\section{Stability condition}

Samples were stored under the conditions recommended by ICH in a stability chamber for 1-, 3- and 6-month periods at $40 \pm 1{ }^{\circ} \mathrm{C}$ and $75 \pm 5 \%$ relative humidity (RH) and at $40 \pm 1{ }^{\circ} \mathrm{C}$ in the absence of humidity (5).

\section{Preparation of standard pancreatin and binary mixtures}

Binary mixtures at a 1:1 ratio $(\mathrm{m} / \mathrm{m})$ were prepared with $30 \mathrm{mg}$ of standard pancreatin and $30 \mathrm{mg}$ of each excipient in a polyethylene container $(3 \mathrm{~cm}$ height $\times 2 \mathrm{~cm}$ diameter). The samples were homogenized by vortexing for $1 \mathrm{~min}$, and stainless steel balls ( $2 \mathrm{~mm}$ diameter) were used to mix the samples. In addition, $30 \mathrm{mg}$ of standard pancreatin was placed in a polyethylene container. All samples were prepared in triplicate.

After the storage time, all samples were solubilized in $25 \mathrm{~mL}$ of TRIS + $\mathrm{HCl}$ buffer (50 mmol L-1, $\mathrm{pH} 7.0$ ) and a stock solution containing $90 \mathrm{U} \mathrm{mL}^{-1} \alpha$-amylase, $7.2 \mathrm{U} \mathrm{mL}^{-1}$ lipase and $90 \mathrm{U} \mathrm{mL}^{-1}$ protease was obtained. These concentrations were estimated from the specification of the standard pancreatin manufacturer, which indicated that $1 \mathrm{mg}$ of standard pancreatin contained 75.0 $\mathrm{U}$ amylase, $6.0 \mathrm{U}$ lipase and 75.0 $\mathrm{U}$ protease.

For $\alpha$-amylase activity determination, a new dilution was prepared using TRIS + HCl buffer (50 mmol L-1 $\mathrm{pH} 7.0$ ) and a solution of $2.0 \mathrm{U} \mathrm{mL}^{-1} \alpha$-amylase was obtained. For lipase, TRIS + $\mathrm{HCl}$ buffer ( $\left.50 \mathrm{mmol} \mathrm{L}^{-1}, \mathrm{pH} 9.0\right)$ was used and a solution containing $6.0 \mathrm{U} \mathrm{mL}^{-1}$ of this enzyme was obtained. Finally, TRIS + $\mathrm{HCl}$ buffer $\left(50 \mathrm{mmol} \mathrm{L}^{-1}, \mathrm{pH} 7.5\right)$ was used to obtain a solution of $14.0 \mathrm{U} \mathrm{mL}^{-1}$ protease. 


\section{Preparation of commercial formulation}

Commercial formulation samples (both whole capsules and the internal powder content) were evaluated. To obtain the powder from the commercial formulation, capsules were opened, the contents were transferred to a mortar and the material was ground and homogenized. The average mass of each capsule was $258 \pm 10 \mathrm{mg}$. According to the label information, each capsule contained 33,200, 10,000 and 37,500 $\mathrm{U}$ of $\alpha$-amylase, lipase and protease, respectively. Then, the enzymes available in $30 \mathrm{mg}$ of homogenized powder were solubilized in TRIS + $\mathrm{HCl}$ buffer $\left(\mathrm{pH}\right.$ 7.0) to prepare a solution containing $153.0 \mathrm{U} \mathrm{mL}^{-1}$ $\alpha$-amylase, $46.0 \mathrm{U} \mathrm{mL}^{-1}$ lipase and $173.0 \mathrm{U} \mathrm{mL}^{-1}$ protease. From this solution, three further dilutions were made using TRIS + $\mathrm{HCl}$ buffer to obtain solutions of $2.0 \mathrm{U} \mathrm{mL}^{-1} \alpha$-amylase, 6.0 $\mathrm{U} \mathrm{mL}^{-1}$ lipase and $14.0 \mathrm{U} \mathrm{mL}^{-1}$ protease.

\section{Stress testing}

A stress test was performed as recommended by ICH (5). In this case, five conditions were applied: high temperature, acidic $\mathrm{pH}$, basic $\mathrm{pH}$, ultraviolet light and forced oxidation. The analyses were conducted according to the procedures described by Blessy et al. and Printz et al. $(6,7)$. Briefly, $2.5 \mathrm{mg}$ of standard pancreatin was weighed and then solubilized in TRIS + $\mathrm{HCl}$ buffer $\left(50 \mathrm{mmol} \mathrm{L}^{-1}, \mathrm{pH} 7.0\right)$. Such solutions of standard pancreatin, having a final volume of $1.0 \mathrm{~mL}$, were prepared in $1.5-\mathrm{mL}$ microtubes. After solubilization, the solutions were centrifuged for 1 minute at 1,000 rpm and then placed in an ultrasound bath. In the prepared samples, the activities were 187.5, 15.0 and $187.5 \mathrm{U} \mathrm{mL}^{-1}$ for a-amylase, lipase and protease, respectively.

For thermal stability testing, the solution containing pancreatin was subjected to $70{ }^{\circ} \mathrm{C}$ for 60 minutes in a water bath and then cooled to room temperature. The choice of temperature was based on the optimal temperature for pancreatin activity $\left(70{ }^{\circ} \mathrm{C}\right.$ induces degradation of all enzymes in the pancreatin complex) (8).

To test the $\mathrm{pH}$ influence, pancreatin samples were subjected to acid $\left(100 \mathrm{mmol} \mathrm{L}^{-1}\right.$ citric acid buffer, $\mathrm{pH} 3.0)$ and base $\left(100 \mathrm{mmol} \mathrm{L}^{-1}\right.$ TRIS + $\mathrm{HCl}$ buffer, $\mathrm{pH} 9.0$ and $50 \mathrm{mmol} \mathrm{L}^{-1}$ carbonate/bicarbonate buffer, $\mathrm{pH}$ 11.0). Activity tests were performed after 60 minutes of exposure. The applied $\mathrm{pH}$ conditions had the objective of providing forced degradation conditions and were selected according to the optimal activity $\mathrm{pH}$ of the main pancreatin enzymes.

The solution of pancreatin was exposed to a photostability chamber with 1.2 million lux-hours of ultraviolet light at $25^{\circ} \mathrm{C}$ for stress tests. Such samples were stored in amber vials and under refrigeration at $4{ }^{\circ} \mathrm{C}$ until analysis. Finally, pancreatin solutions were prepared in $50 \mathrm{mmol} \mathrm{L}^{-1}$ TRIS+HCl buffer, $\mathrm{pH} \mathrm{7.0,} \mathrm{and} 3 \%(v / v)$ hydrogen peroxide for forced oxidation. All of stress tests were performed in triplicate and samples were analyzed for activity as soon as the tests were completed.

\section{Spectrophotometric analyses}

Spectrophotometric analyses were performed using a spectrophotometer (UV-Vis 1800 , Shimadzu, Japan). In these analyses, the limit of quantification (LOQ) was calculated as 10 times the ratio between the standard deviation of the blank and the slope of the respective calibration curve. 
$\alpha$-amylase. - The method was based on the measurement of amylolytic activity through quantification of the reducing sugars given off by the starch hydrolysis reaction, catalyzed by amylases. The reducing sugars were quantified at $550 \mathrm{~nm}$. The $\alpha$-amylase activity was determined based on the methodology described by ANVISA and Russel $(9,10)$.

Lipase. - The lipase activity was determined through quantification of the product formed by the lipase-catalyzed hydrolysis of $p$-nitrophenyl palmitate. The chromogen product was quantified at $410 \mathrm{~nm}$. The lipase activity analyses were performed based on the method described by Kanwar (11) and Abd-Elhakeem (12).

Protease. - The proteolytic activity was determined by quantification of the azo compound released during the hydrolysis of the chromogenic substrate azocasein. The protease activity was determined at $400 \mathrm{~nm}$ based on the methodology described by ANVISA (9).

\section{RESULTS AND DISCUSSION}

Each enzyme of the pancreatin complex showed a different degradation profile, which was strongly influenced by distinct storage conditions. This profile could be accompanied by changes as a function of time (initial, 1-, 3- and 6-months), allowing a detailed analysis of the behavior of enzyme activities during storage.

In stability analyses, one hundred \% of the activity of each enzyme was assumed from the absorbance obtained from the standard pancreatin solution containing $2.0 \mathrm{U} \mathrm{mL}^{-1}$ $\alpha$-amylase, $6.0 \mathrm{U} \mathrm{mL}^{-1}$ lipase, and $14.0 \mathrm{U} \mathrm{mL}^{-1}$ protease.

\section{Stability of $\alpha$-amylase}

When stored at $40{ }^{\circ} \mathrm{C}$ and $75 \% \mathrm{RH}$ (Table I), a total decline in activity of this enzyme was observed in just one month when the pancreatin was stored in the absence and presence of all excipients. This finding shows that humidity exerts a strong influence on $\alpha$-amylase stability, inducing its degradation. Thus, none of the evaluated excipients was able to provide a protective effect for $\alpha$-amylase. In the commercial formulation sample, the activity (only $12.5 \%$ of activity was found both in the capsule and powder) decreased considerably, showing that the combination of temperature and humidity exerts a strong negative influence on $\alpha$-amylase stability, inducing a distortion of the enzyme structure. The same profile was observed when the commercial formulation was analyzed after 3 months.

When $\alpha$-amylase was analyzed after 1 month of storage at $40{ }^{\circ} \mathrm{C}$ and $0 \% \mathrm{RH}$ (Table I), its activity was $61.0 \%$ of the activity when pancreatin was stored without excipients. However, sucrose and mannitol showed protective effects on $\alpha$-amylase activities (79.5 and $68.0 \%$, respectively). The other excipients did not provide effective protection. After 3 months, $\alpha$-amylase activities were low in all samples. However, sucrose still showed a protective effect on this enzyme, maintaining its activity at $52.0 \%$. After 6 months, $\alpha$-amylase showed activity lower than the $L O Q$ for the pancreatin standard stored without excipients. In the commercial formulation sample, higher preservation of activity was observed compared to that for the samples stored with humidity. 
Table I. Activity of $\alpha$-amylase (\%) in pancreatin samples stored at $40{ }^{\circ} \mathrm{C}$ and $75 \% \mathrm{RH}$ and $40{ }^{\circ} \mathrm{C}$ and $0 \% \mathrm{RH}$ after different times of incubation ${ }^{a}$

\begin{tabular}{lccccccc}
\hline \multirow{2}{*}{ Sample } & \multirow{2}{*}{$\begin{array}{c}\text { Initial } \\
\text { value }\end{array}$} & \multicolumn{3}{c}{ With humidity } & \multicolumn{4}{c}{ No humidity } \\
\cline { 3 - 8 } & & 1-month & 3-months & 6-months & 1-month & 3-months & 6-months \\
\hline Pancreatin & $98.3 \pm 0.9$ & $\leq L O Q$ & $\leq L O Q$ & $\leq L O Q$ & $61.0 \pm 0.7$ & $33.0 \pm 0.7$ & $\leq L O Q$ \\
P + citric acid & $99.1 \pm 0.9$ & $\leq L O Q$ & $\leq L O Q$ & $\leq L O Q$ & $13.3 \pm 0.5$ & $\leq L O Q$ & $\leq L O Q$ \\
$P$ + sacharose & $97.6 \pm 0.9$ & $\leq L O Q$ & $\leq L O Q$ & $\leq L O Q$ & $79.5 \pm 0.9$ & $52.0 \pm 0.7$ & $11.0 \pm 0.8$ \\
$P$ + mannitol & $98.7 \pm 1.1$ & $\leq L O Q$ & $\leq L O Q$ & $\leq L O Q$ & $68.0 \pm 0.6$ & $33.0 \pm 0.6$ & $4.5 \pm 0.5$ \\
$P$ + cellulose & $98.4 \pm 1.3$ & $\leq L O Q$ & $\leq L O Q$ & $\leq L O Q$ & $2.5 \pm 0.1$ & $\leq L O Q$ & $\leq L O Q$ \\
$P+$ Mg-stearate & $99.5 \pm 1.1$ & $\leq L O Q$ & $\leq L O Q$ & $\leq L O Q$ & $43.5 \pm 0.7$ & $17.5 \pm 0.6$ & $4.5 \pm 0.5$ \\
$P$ + talc & $98.1 \pm 1.2$ & $\leq L O Q$ & $\leq L O Q$ & $\leq L O Q$ & $17.0 \pm 0.7$ & $4.5 \pm 0.3$ & $\leq L O Q$ \\
Capsule & $92.5 \pm 0.6$ & $12.5 \pm 0.4$ & $5.7 \pm 0.6$ & - & $69.0 \pm 0.7$ & $26.6 \pm 0.8$ & - \\
Powder & $90.2 \pm 0.4$ & $12.5 \pm 0.3$ & $3.2 \pm 0.5$ & - & $55.0 \pm 0.6$ & $23.5 \pm 0.7$ & - \\
\hline
\end{tabular}

P - Pancreatin standard

${ }^{\mathrm{a}}$ Mean $\pm \mathrm{SD}, n=3$.

${ }^{\mathrm{b}} \leq L O Q-2.2 \%$ of activity.

${ }^{\mathrm{c}}$ Period of storage not evaluated.

\section{Stability of lipase}

Lipase had a very similar stability profile under both conditions; this enzyme showed higher activity levels in binary mixtures and the pancreatin standard. After 1 month at $40{ }^{\circ} \mathrm{C}$ and $75 \%$ RH (Table II), lipase showed activity of $66.3 \pm 0.9 \%$ in the absence of excipients. The only excipient that showed a protective effect was sucrose, which maintained the enzymatic activity at $88.7 \pm 0.9 \%$. The other excipients (citric acid, mannitol, cellulose, magnesium stearate and talc) led to lower enzymatic activity than the activity of standard pancreatin. After 6 months, the mixtures with mannitol, magnesium stearate and talc showed a decrease in lipase activity ( $L O Q \leq 3.3 \%)$.

In the commercial formulation samples, a drastic decrease in lipase activity was observed for the storage at $40{ }^{\circ} \mathrm{C}$ and $75 \% \mathrm{RH}$, further demonstrating that humidity exerts a strong negative influence on enzyme structure. This finding indicates that the effectiveness of the commercial formulation is compromised under such conditions.

In contrast to the results for humidity conditions, sucrose did not show a protective effect on lipase activity. Independently of incubation time, samples with magnesium stearate stored at $40{ }^{\circ} \mathrm{C}$ and $0 \% \mathrm{RH}$ showed the highest lipase activities compared to the standard pancreatin sample. The magnesium stearate effect on lipase activity is interesting and could be attributed to enzyme affinity for hydrophobic excipients, such as stearate, which interact with the enzyme active site and reduce its three-dimensional distortion (13). When lipase activities were determined for the commercial formulation after 1 month, there was better preservation of this enzyme (75 and $64 \%$ in the capsule and powder, respectively). After 3 months, a low level of activity was observed (14.5 and $16.3 \%$ in the same previ- 
Table II. Activity of lipase (\%) in pancreatin samples stored at $40{ }^{\circ} \mathrm{C}$ and $75 \% \mathrm{RH}$ and $40{ }^{\circ} \mathrm{C}$ and $0 \%$ RH after different times of incubation ${ }^{a}$

\begin{tabular}{lccccccc}
\hline \multirow{2}{*}{ Sample } & \multirow{2}{*}{$\begin{array}{c}\text { Initial } \\
\text { value }\end{array}$} & \multicolumn{3}{c}{ With humidity } & \multicolumn{4}{c}{ No humidity } \\
\cline { 3 - 8 } & & 1-month & 3-months & 6-months & 1-month & 3-months & 6-months \\
\hline Pancreatin & $100.0 \pm 0.2$ & $66.3 \pm 0.9$ & $24.4 \pm 0.7$ & $7.6 \pm 0.6$ & $60.6 \pm 0.5$ & $21.0 \pm 0.9$ & $7.6 \pm 0.6$ \\
P + citric acid & $97.7 \pm 0.2$ & $24.9 \pm 0.7$ & $9.6 \pm 0.7$ & $\leq L O Q$ & $43.6 \pm 0.5$ & $15.0 \pm 0.5$ & $2.8 \pm 0.4$ \\
P + sacharose & $99.3 \pm 0.7$ & $88.7 \pm 0.9$ & $50.1 \pm 0.4$ & $15.0 \pm 0.9$ & $29.7 \pm 0.7$ & $12.7 \pm 0.9$ & $3.4 \pm 0.6$ \\
P + mannitol & $98.2 \pm 0.4$ & $27.5 \pm 0.2$ & $7.4 \pm 0.4$ & $\leq L O Q$ & $24.9 \pm 0.8$ & $9.9 \pm 0.5$ & $\leq L O Q$ \\
P + cellulose & $98.3 \pm 0.9$ & $48.4 \pm 0.2$ & $15.0 \pm 0.9$ & $3.4 \pm 0.5$ & $37.7 \pm 0.9$ & $17.6 \pm 0.2$ & $7.6 \pm 0.5$ \\
P + Mg-stearate & $98.2 \pm 0.9$ & $23.2 \pm 0.5$ & $7.1 \pm 0.8$ & $\leq L O Q$ & $66.0 \pm 0.8$ & $47.3 \pm 0.6$ & $23.7 \pm 0.6$ \\
P + talc & $98.1 \pm 0.9$ & $24.6 \pm 0.8$ & $7.1 \pm 0.7$ & $\leq L O Q$ & $44.7 \pm 0.7$ & $23.8 \pm 0.3$ & $9.1 \pm 0.3$ \\
Capsule & $90.3 \pm 0.3$ & $26.0 \pm 0.6$ & $13.0 \pm 0.8$ & - & $75.0 \pm 0.3$ & $16.3 \pm 0.5$ & - \\
Powder & $91.3 \pm 0.8$ & $13.5 \pm 0.7$ & $8.2 \pm 0.3$ & - & $64.0 \pm 0.4$ & $14.5 \pm 0.7$ & - \\
\hline
\end{tabular}

P - Pancreatin standard

${ }^{\mathrm{a}}$ Mean $\pm \mathrm{SD}, n=3$.

${ }^{\mathrm{b}} \leq L O Q-3.3 \%$ of activity.

${ }^{\mathrm{c}}$ Period of storage not evaluated.

ously mentioned samples). Further, in this case, the capsules did not have an adequate protective effect on the active pharmaceutical ingredient.

\section{Stability of protease}

After 1 month at $40{ }^{\circ} \mathrm{C}$ and $75 \% \mathrm{RH}$ (Table III), the protease activity in the pancreatin standard decreased considerably (only $8.3 \pm 0.5 \%$ of the activity was detected). Sucrose and cellulose did not significantly affect the protease activity (no significant differences were found after applying the $t$-test at the $95 \%$ confidence level for comparison with standard pancreatin). This effect is likely due to the chiral centers of enzymes (14). The presence of mannitol, magnesium stearate and talc further decreased protease activities. However, citric acid increased the protease activity to approximately two times the value of pure standard pancreatin. Thus, citric acid exerted a protective effect under conditions of humidity storage. In the commercial formulation, the detected activity was 77.9 and $48.4 \%$ in the capsule and powder, respectively.

When this enzyme was analyzed after 1 month at $40{ }^{\circ} \mathrm{C}$ and $0 \% \mathrm{RH}$ (Table III), a total decrease in activity was observed in the pancreatin standard ( $L O Q \leq 2.6 \%$ ). The same behavior was observed when the sample was mixed with citric acid. However, some excipients, such as cellulose and talc, showed a slight protective effect. After 3 and 6 months, a total decrease in protease activity was observed for both storage conditions. Amino acid residues (mainly cysteine) can interfere with enzyme activity. These structures are likely to combine with essential amino acids, thus decreasing the enzyme conformational stability and consequently reducing its activity (15). 
Table III. Activity of protease (\%) in pancreatin samples stored at $40{ }^{\circ} \mathrm{C}$ and $75 \% \mathrm{RH}$ and $40{ }^{\circ} \mathrm{C}$ and $0 \% \mathrm{RH}$ after different times of incubation

\begin{tabular}{|c|c|c|c|c|c|c|c|}
\hline \multirow{2}{*}{ Sample } & \multirow{2}{*}{$\begin{array}{l}\text { Initial } \\
\text { value }\end{array}$} & \multicolumn{3}{|c|}{ With humidity } & \multicolumn{3}{|c|}{ No humidity } \\
\hline & & 1-month & 3-months & 6-months & 1-month & 3-months & 6-months \\
\hline Pancreatin & $100.0 \pm 0.3$ & $8.3 \pm 0.5$ & $\leq L O Q$ & $\leq L O Q$ & $\leq L O Q$ & $\leq L O Q$ & $\leq L O Q$ \\
\hline $\mathrm{P}+$ citric acid & $98.5 \pm 0.4$ & $19.8 \pm 0.5$ & $\leq L O Q$ & $\leq L O Q$ & $\leq L O Q$ & $\leq L O Q$ & $\leq L O Q$ \\
\hline $\mathrm{P}+$ sacharose & $99.5 \pm 0.7$ & $8.8 \pm 0.5$ & $\leq L O Q$ & $\leq L O Q$ & $2.9 \pm 0.6$ & $\leq L O Q$ & $\leq L O Q$ \\
\hline $\mathrm{P}+$ mannitol & $98.5 \pm 0.8$ & $3.4 \pm 0.6$ & $\leq L O Q$ & $\leq L O Q$ & $4.6 \pm 0.4$ & $\leq L O Q$ & $\leq L O Q$ \\
\hline $\mathrm{P}+$ cellulose & $98.5 \pm 0.8$ & $8.0 \pm 0.5$ & $\leq L O Q$ & $\leq L O Q$ & $11.0 \pm 0.5$ & $\leq L O Q$ & $\leq L O Q$ \\
\hline $\mathrm{P}+\mathrm{Mg}$-stearate & $99.0 \pm 0.6$ & $2.9 \pm 0.6$ & $\leq L O Q$ & $\leq L O Q$ & $2.9 \pm 0.6$ & $\leq L O Q$ & $\leq L O Q$ \\
\hline $\mathrm{P}+$ talc & $98.3 \pm 0.8$ & $5.4 \pm 0.5$ & $\leq L O Q$ & $\leq L O Q$ & $5.4 \pm 0.5$ & $\leq L O Q$ & $\leq L O Q$ \\
\hline Capsule & $96.3 \pm 0.6$ & $77.9 \pm 0.9$ & $27.0 \pm 0.8$ & - & $91.7 \pm 0.3$ & $43.0 \pm 0.4$ & - \\
\hline Powder & $96.4 \pm 0.5$ & $48.4 \pm 0.4$ & $24.5 \pm 0.2$ & - & $82.3 \pm 0.7$ & $37.9 \pm 0.3$ & - \\
\hline
\end{tabular}

Pancreatin $-\mathrm{P}$

${ }^{\text {a Mean }} \pm \mathrm{SD}, n=3$.

${ }^{\mathrm{b}} \leq L O Q-2.6 \%$ of activity.

${ }^{\mathrm{c}}$ Period of storage not evaluated

Table IV. Activity of enzymes in pancreatin samples subjected to stress testing

\begin{tabular}{lcccccc}
\hline \multirow{2}{*}{ Sample } & \multicolumn{2}{c}{$\alpha$-amylase } & \multicolumn{2}{c}{ Lipase } & \multicolumn{2}{c}{ Protease } \\
\cline { 2 - 7 } & DF & Activity $(\%)^{\mathrm{b}}$ & DF & Activity $(\%)^{\mathrm{b}}$ & DF $^{\mathrm{a}}$ & Activity $(\%)^{\mathrm{b}}$ \\
\hline No stress & 100 & $100.2 \pm 0.3$ & 2.5 & $102.3 \pm 0.8$ & 13 & $100.3 \pm 0.4$ \\
pH 3.0 & - & $0.3 \pm 0.1$ & - & $15.4 \pm 0.4$ & - & $4.1 \pm 0.2$ \\
pH 9.0 & 100 & $101.2 \pm 0.9$ & 2.5 & $94.4 \pm 0.5$ & 13 & $73.1 \pm 0.3$ \\
pH 11.0 & - & $0.1 \pm 0.02$ & - & $10.9 \pm 0.3$ & - & $3.6 \pm 0.1$ \\
Temperature & - & $2.1 \pm 0.03$ & - & $7.5 \pm 0.2$ & - & $1.8 \pm 0.1$ \\
Oxidation & - & $0.3 \pm 0.02$ & - & $32.2 \pm 0.2$ & 13 & $54.1 \pm 0.4$ \\
UV light & 100 & $100.2 \pm 0.2$ & - & $5.9 \pm 0.2$ & - & $2.1 \pm 0.2$ \\
\hline
\end{tabular}

${ }^{a} \mathrm{DF}$ - dilution factor.

${ }^{\mathrm{b}}$ without dilution.

${ }^{\mathrm{c}}$ Mean $\pm \mathrm{SD}, n=3$.

\section{Activity of samples subjected to stress testing}

As shown by the data in Table IV, the $\alpha$-amylase activity was completely maintained at $\mathrm{pH} 9.0$ and when subjected to UV light. No significant differences between the sets of results were found after applying the $t$-test at the $95 \%$ confidence level. Further, other stress testing conditions were extremely harmful, resulting in activity lower than $2.1 \%$. 
In contrast, significant alterations in lipase activity were observed under all stress testing conditions, as indicated by the same statistical parameters. It is important to emphasize that lipase is the main enzyme of the pancreatin complex.

The conditions that best preserved protease activity were $\mathrm{pH} 9.0$ and oxidation. Other conditions (acid $\mathrm{pH}$, temperature, $\mathrm{UV}$ light and $\mathrm{pH} 11.0$ ) were extremely harmful to protease activity (activities lower than $4.1 \%$ were detected).

For three enzymes, acidic $\mathrm{pH}$, highly basic $\mathrm{pH}(\mathrm{pH} 11.0)$ and high temperature $\left(70{ }^{\circ} \mathrm{C}\right.$ for 60 minutes), exposure induced considerable losses in activities. Therefore, attention should be paid to the appropriate $\mathrm{pH}$ and temperature during the preparation and storage of formulations containing pancreatin.

\section{CONCLUSIONS}

The $\alpha$-amylase and protease activities decreased significantly after 1-month storage at $40{ }^{\circ} \mathrm{C}$ and $75 \% \mathrm{RH}$. The protease activity also decreased without humidity; thus, this enzyme was most susceptible to degradation. In contrast, lipase showed the highest stability (indicated by higher activity levels). The results demonstrate that the proprieties of chemical excipients can affect enzyme stability and, consequently, its activity. Sucrose was the excipient with the best protective effect on $\alpha$-amylase and lipase in samples stored with humidity. In addition, the enzymatic activity study of the commercial formulation after 3 months under both storage conditions showed a substantial decrease in all enzyme activities. This result indicates that the efficiency of the commercial formulation is compromised.

The stress testing data indicate that exposure to $\mathrm{pH} 3.0, \mathrm{pH} 11.0$ and temperature induces considerable losses in the activities of the three enzymes. Attention should be paid to $\mathrm{pH}$, temperature and humidity during the preparation and storage of pharmaceutical pancreatin formulations.

Acknowledgments. - Thanks are due to the Coordenação de Aperfeiçoamento de Pessoal de Nível Superior (CAPES), to the Conselho Nacional de Desenvolvimento Científico e Tecnológico (Processo: CNPq 552387/2011-8, Projeto Casadinho PROCAD), and to the Fundação de Amparo à Pesquisa do Estado de Minas Gerais (FAPEMIG) for the financial support.

\section{REFERENCES}

1. R. Noor, N. Zerin and K. K. Das, Microbiological quality of pharmaceutical products in Bangladesh: Current research perspective, Asian Pac. J. Trop. Dis. 5 (2015) 264-270; DOI: 10.1016/s22221808(14)60781-7.

2. E. Tamizi and A. Jouyban, Forced degradation studies of biopharmaceuticals: Selection of stress conditions, Eur. J. Pharm. Biopharm. 98 (2016) 26-46; DOI: 10.1016/j.ejpb.2015.10.016.

3. United States Pharmacopeia 32, National Formulary 27, USP Convention, Rockville 2010.

4. A. V. Berdutina, A. D. Neklyudov, A. I. Ivankin, B. S. Karpo and S. I. Mitaleva, Comparison of proteolytic activities of the enzyme complex from mammalian pancreas and pancreatin, Appl. Biochem. Micro. 36 (2000) 363-367.

5. International Conference on Harmonization of Technical Requirements for Registration of Pharmaceuticals for Human Use, ICH Harmonized Tripartite Guideline, Quality of Biotechnological Products: Stability Testing of Biotechnological/Biological Products Q5C, November 1995. 
6. M. Blessy, R. D. Patel, P. N. Prajapati and Y. K. Agrawal, Development of forced degradation and stability indicating studies of drugs - A review, J. Pharm. Anal. 4 (2014) 159-165; DOI: 10.1016/j. jpha.2013.09.003.

7. M. Printz and W. Friess, Simultaneous detection and analysis of protein aggregation and protein unfolding by size exclusion chromatography with post column addition of the fluorescent dye BisANS, J. Pharm. Sci. 101 (2012) 826-837; DOI: 10.1002/jps.22808.

8. K. Singh and A. M. Kayastha, Amylase from wheat (Triticum aestivun) seeds: its purification, biochemical attributes and active site studies, Food Chem. 162 (2014) 1-9; DOI: 10.1016/j.foodchem.2014.04.043.

9. ANVISA. Resolução da diretoria colegiada - RDC no 55 de 14 de novembro de 2012; http://portal. anvisa.gov.br/wps/wcm/connect/5b22ac004d9a646fb63ff7c116238c3b/27+de+novembro+RDC+55_2 012++Detergentes+Enzimaticos.pdf?MOD=AJPERES; access date March 16, 2015.

10. J. Russell, Measuring amylase activity in cereal grains, J. Res. Meth. 9 (2007) 11-13.

11. S. S. Kanwar, R. K. Kaushal, A. Jawed, R. Gupta and S. S. Chimni, Methods for inhibitions of residual lipase activity in colorimetric assay: A comparative study, Indian J. Biochem. Bio. 42 (2005) 233-237.

12. M. A. Abd-Elhakeem, A. M. Elsayed and T. A. Alkhulaqi, New colorimetric method for lipases Activity assay in microbial media, Am. J. Anal. Chem. 4 (2013) 442-444; DOI: 10.4236/ajac.2013.49055.

13. L. Scalvini, D. Piomelli and M. Mor, Monoglyceride lipase: structure and inhibitors, Chem. Phys. Lipids 197 (2016) 13-24; DOI: 10.1016/j.chemphyslip.2015.07.011.

14. K. C. Waterman, R. C. Adami, K. M. Alsante, J. Hong, M. S. Landis, F. Lombardo and C. J. Roberts, Stabilization of pharmaceuticals to oxidative degradation, Pharm. Dev. Technol. 7 (2002) 1-32; DOI: 10.1081/PDT-120002237.

15. E. Buxbaum, Biophysical Chemistry of Protein. An Introduction to Laboratory Methods, $1^{\text {st }}$ ed., Springer, New York 2011. 